\title{
Waste Is the New Wealth - Recovering Resources From Poultry Wastewater for Multifunctional Microalgae Feedstock
}

OPEN ACCESS

Edited by:

Ronald Halim

University College Dublin, Ireland

Reviewed by:

Geetanjali Yadav,

National Renewable Energy Laboratory (DOE), United States

Alberto Reis,

Laboratório Nacional de Energia e Geologia, Portugal

${ }^{*}$ Correspondence:

Eli S. J. Thoré

eli.thore@thomasmore.be

Specialty section:

This article was submitted to Water and Wastewater Management,

a section of the journal

Frontiers in Environmental Science

Received: 12 March 2021 Accepted: 22 June 2021

Published: 06 July 2021

Citation:

Thoré ESJ, Schoeters F, De Cuyper A, Vleugels $R$, Noyens I, Bleyen $P$ and Van Miert S (2021) Waste Is the New Wealth - Recovering Resources From Poultry Wastewater for Multifunctional Microalgae Feedstock.

Front. Environ. Sci. 9:679917. doi: 10.3389/fenvs.2021.679917

\section{Eli S. J. Thoré ${ }^{1 *}$, Floris Schoeters ${ }^{1}$, Audrey De Cuyper ${ }^{1}$, Rut Vleugels ${ }^{1}$, Isabelle Noyens ${ }^{1}$, Peter Bleyen ${ }^{2}$ and Sabine Van Miert ${ }^{1}$}

${ }^{1}$ Radius, Thomas More University of Applied Sciences, Geel, Belgium, ${ }^{2} E V A P$ Proefbedrijf Pluimveehouderij, Geel, Belgium

To meet the increasing demands of the growing population and to cope with the challenges of global change, both the production of biological feedstock and the recovery of recyclable natural resources play a critical role. Microalgal biomass is a promising source of renewable multifunctional feedstock, but the production is costly and requires large amounts of water. Here, we explored the potential of using wastewater as culture medium to lower the economic and environmental costs of microalgae biomass production and evaluated its valorization opportunities for animal feed production. As a proof of principle, we show that Chlorella sorokiniana can be cultivated on poultry wastewater, with a 83 and $113 \%$ increase in productivity when wastewater was first $50 \%$ diluted with tap water or standard growth medium, respectively. Wastewater sterilization before use enhanced algal growth with $36-118 \%$, but only when wastewater was 25-50\% diluted with standard medium. In contrast, it offered no additional benefits when dilutions were made with tap water or when wastewater was not diluted. At the end of the 22-days experiment, a maximum biomass of $0.8-1.9 \mathrm{~g} \mathrm{~L}^{-1}$ was reached for algae grown on wastewater. The produced biomass had a high macronutrient content, and the heavy metal content was below maximum limits for use in animal feed. Likewise, the tested pathogen groups were reduced until below safety norms for feed production after algal growth in unsterilized 50\% wastewater (diluted with tap water). Overall, these findings add to our growing knowledge on the cultivation of microalgae on wastewater and its valorization opportunities, paving the way for a more sustainable use and reuse of resources.

Keywords: circular economy, bioeconomy, sustainability, bioresource, biotechnology, algae, waste valorization

\section{INTRODUCTION}

Manufacturing processes are depleting the Earth's resources (Kümmerer et al., 2020), while increasing amounts of valuable materials are lost as waste that may adversely affect the environment and human health (Waters et al., 2016; Sinha et al., 2017). Because decreasing primary resources and increasing waste are key factors that threaten a sustainable society for future generations (Clark, 2019), it is essential to sustainably provide goods and services across economic sectors (Geng et al., 2019; Kümmerer et al., 2020). For this, the production of biological 
feedstock and the recovery of recyclable natural resources play a critical role (El-Chichakli et al., 2016; Clark, 2019). This presents a shift from our current linear economic model of mine-processconsume-dispose that is largely dependent on mineral resources to a more circular model in which the production of environmentally compatible, recyclable products is a central feature (Clark, 2019).

While the global demand for resources is projected to double by 2050 (Schandl et al., 2016) and the economic and environmental costs of manufacturing materials are increasing (Kümmerer et al., 2020), several nations are rallying to the cause by boosting their bioeconomy and opening new revenue streams from materials that would otherwise be lost as waste (ElChichakli et al., 2016). Nevertheless, despite many valuable initiatives to link supply chains and reuse or recycle materials, to date still only $6 \%$ of materials are recycled and more initiatives are needed to advance the global circular economy (Haas et al., 2015; Geng et al., 2019).

In recent years, microalgal biomass has been promoted as a promising source of renewable feedstock for a range of economic sectors (Rösch et al., 2019). Microalgae are a diverse group of single-celled organisms, most of which are photosynthetic, occurring in a wide variety of habitats (Metting, 1996; Wild et al., 2019). The diversity of microalgae enables their cultivation in various technical systems that, in contrast to traditional crops, are not dependent on arable land and pesticides (Rösch et al., 2019; Nagarajan et al., 2020). They have an outstanding biomass productivity and are rich sources of various marketable, highvalue compounds including proteins, lipids and polysaccharides that can be used as feedstock for diverse economic sectors (Becker, 2013; Chew et al., 2017; Rösch et al., 2019).

Microalgae farming gains traction globally due to the anticipated wealth of application opportunities, yet the current commercialization of algae technology lags far behind expectations (Rösch et al., 2019; Vigani, 2020). This is largely due to high operating and environmental costs that hamper the economic viability and sustainability of the technology (Norsker et al., 2011; Nagarajan et al., 2020). For instance, the microalgal cultivation process needs large amounts of water and nutrients, which adds to the water footprint and the total operating costs (Acién Fernández et al., 2019; Guldhe et al., 2017; Wang et al., 2018). This is further exacerbated by natural nutrient reserves such as phosphorus resources that become increasingly scarce and expensive (Cordell and White, 2014). In contrast, many wastewaters are enriched with various macro- and micronutrients that are essential for microalgal growth, including carbon, nitrogen, phosphorus and various trace minerals (Alcántara et al., 2015; Guldhe et al., 2017; Wang et al., 2018). While excess nutrients in wastewater are often lost to the environment (Larsen et al., 2016; Slompo et al., 2020), recovering resources from wastewater may reduce the water footprint and operating costs of algae cultivation (Guldhe et al., 2017; Nagarajan et al., 2020). This, combined with the versatility of microalgae to grow under various conditions (Metting, 1996; Nagarajan et al., 2020), offers an interesting revenue stream to produce renewable, biological feedstock from waste.
While this approach has primarily been suggested for the production of affordable bioenergy feedstock (Bhatia et al., 2020; Wicker et al., 2021), integrating such applications with food and feed development may further fuel the economic viability of microalgal farming (Rösch et al., 2019). Producing algal feedstock on wastewater for multiple applications firmly adheres to the principles of circular bio-economy (Rösch et al., 2019; Bos and Broeze, 2020), but it currently suffers from a number of technical and legal limitations. Challenges predominantly pertain to reaching a sufficiently high biomass productivity without the need for expensive pretreatment of the wastewater (Guldhe et al., 2017; Clark, 2019), as well as meeting the quality and safety standards for the food/feed sector (Guldhe et al., 2017; Rösch et al., 2019). Therefore, implementing this method first requires a better understanding of which wastewater conditions favor microalgal biomass production, and how this affects the quality and safety of the biomass.

To examine this, we first screened the growth potential of several microalgae species on sterilized and non-sterilized wastewater dilutions under laboratory conditions to estimate their tolerance to the wastewater. To this end, wastewater from poultry farming (i.e., rinsing water from broiler chicken barns) was used as a cheap yet nutrient-rich substrate. We focused on sterilization and dilution as common pretreatment strategies to reduce undesirable microorganisms and to lower wastewater toxicity, respectively (Guldhe et al., 2017). Dilutions were either made with standard algae growth medium or with tap water as a cheaper alternative. Next, we selected the most promising species and ran a more detailed experiment to assess how wastewater sterilization and-dilution affect microalgal growth. Nutrient removal as well as the quality and safety of the biomass for feed applications was assessed, including a quantitative analysis of the different macronutrients, amino acid composition, the accumulation of heavy metals, and presence of specific pathogens. These assessments aim to support the development of a circular economy by shedding light on microalgae cultivation using wastewater and its valorization opportunities for animal feed production.

\section{MATERIALS AND METHODS Microalgal Strains and Stock Culture Conditions}

Acutodesmus obliquus (SAG 276-3d), Chlorella sorokiniana (SAG 211-31), C. vulgaris (SAG 211-12), Desmodesmus armatus (SAG 276-4d), Microchloropsis (Nannochloropsis) gaditana (SAG 2.99), and Parachlorella kessleri (SAG 12.80) strains were purchased from SAG (Department Experimental Phycology and Culture Collection of Algae, University of Goettingen, Germany). Stock cultures of these strains were initially grown in $250 \mathrm{ml}-$ erlenmeyers on an orbital shaker at $90 \mathrm{rpm}$ to mix the cultures, with $70 \mu \mathrm{mol} \mathrm{m}^{-2} \mathrm{~s}^{-1}$ light exposure (cool-white fluorescent, top-illumination) in a climate-controlled room at $22^{\circ} \mathrm{C}( \pm 0.17 \mathrm{SD})$ under a $16 / 8$-h light/dark regime. These cultures 
were then transferred to aerated glass $1 \mathrm{~L}$-bottles for further growth to provide the desired algae-inoculum for the experiments. Sterile freshwater medium was used for $A$. obliquus, C. sorokiniana, C. vulgaris, D. armatus and $P$. kessleri. This medium had the following composition (based on SAG basal medium version 10.2008): $252 \mathrm{mg} / \mathrm{L} \mathrm{HNO}_{3}$, $22 \mathrm{mg} / \mathrm{L} \mathrm{H}_{3} \mathrm{PO}_{4}, 248 \mathrm{mg} / \mathrm{L} \mathrm{KOH}, 6.3 \mathrm{mg} / \mathrm{L} \mathrm{Fe}-\mathrm{DTPA}, 42 \mathrm{pg} / \mathrm{L}$ $\mathrm{CuSO}_{4} .5 \mathrm{H}_{2} \mathrm{O}, \quad 2.8 \mu \mathrm{g} / \mathrm{L} \quad \mathrm{ZnSO}_{4}, \quad 7.2 \mu \mathrm{g} / \mathrm{L} \quad \mathrm{MnSO}_{4}, \quad 4.3 \mu \mathrm{g} / \mathrm{L}$ $\mathrm{Na}_{2} \mathrm{MoO}_{4}, 40 \mu \mathrm{g} / \mathrm{L} \quad \mathrm{Na}_{2} \mathrm{~B}_{4} \mathrm{O}_{7}, 0.2 \mathrm{~g} / \mathrm{L} \quad \mathrm{NaHCO}_{3}$ and $23 \mathrm{mg} / \mathrm{L}$ $\mathrm{MgSO}_{4} \cdot 7 \mathrm{H}_{2} \mathrm{O}$. M. gaditana was cultivated in sterile brackish medium with the following composition (based on SAG brackish water medium, version 10.2008): $252 \mathrm{mg} / \mathrm{L} \mathrm{HNO}_{3}$, $22 \mathrm{mg} / \mathrm{L} \mathrm{H}_{3} \mathrm{PO}_{4}, 248 \mathrm{mg} / \mathrm{L} \mathrm{KOH}, 6.3 \mathrm{mg} / \mathrm{L} \mathrm{Fe}-\mathrm{DTPA}, 42 \mathrm{pg} / \mathrm{L}$ $\mathrm{CuSO}_{4} .5 \mathrm{H}_{2} \mathrm{O}, \quad 2.8 \mu \mathrm{g} / \mathrm{L} \quad \mathrm{ZnSO}_{4}, \quad 7.2 \mu \mathrm{g} / \mathrm{L} \quad \mathrm{MnSO}_{4}, \quad 4.3 \mu \mathrm{g} / \mathrm{L}$ $\mathrm{Na}_{2} \mathrm{MoO}_{4}, \quad 40 \mu \mathrm{g} / \mathrm{L} \quad \mathrm{Na}_{2} \mathrm{~B}_{4} \mathrm{O}_{7}, \quad 0.2 \mathrm{~g} / \mathrm{L} \quad \mathrm{NaHCO}_{3}, \quad 3.15 \mathrm{~g} / \mathrm{L}$ $\mathrm{MgSO}_{4} .7 \mathrm{H}_{2} \mathrm{O}, 11.8 \mathrm{~g} / \mathrm{L} \mathrm{NaCl}$ and $0.315 \mathrm{~g} / \mathrm{L} \mathrm{CaCl} 2.2 \mathrm{H}_{2} \mathrm{O}$.

\section{Preparation of Culture Media Preparation of Poultry Wastewater}

Poultry wastewater is produced from the periodical rinsing of broiler chicken barns and drinking lines to limit the build-up of wet manure and to promote animal health. The resulting wastewater is then collected in a cesspit until it is disposed of. Prior to experimentation, wastewater samples were taken at three random moments (04/02/'20, 18/02/'20 and 05/03/'20) to determine its physicochemical properties (including variation) following accredited methods: $\mathrm{pH}$ : $6.83 \pm 0.08$ (WAC/III/A/005); Electrical conductivity: $1839.67 \pm 70.04 \mu \mathrm{S} / \mathrm{cm}$ (WAC/III/A/004); BOD: $793.33 \pm 161.97 \mathrm{mg} \mathrm{O}_{2} / \mathrm{L}$ (WAC/III/D/010); TOC: $246.67 \pm$ $50.33 \mathrm{mg} \mathrm{C} / \mathrm{L}(\mathrm{SM} 00910(\mathrm{CN}))$; Total N: $161.33 \pm 12.74 \mathrm{mg} / \mathrm{L}$ (WAC/III/D), $\mathrm{NH}_{4}{ }^{+}-\mathrm{N}: 108.33 \pm 7.64 \mathrm{mg} / \mathrm{L}(\mathrm{WAC} / \mathrm{III} / \mathrm{E} / 022)$; Total P: $24.33 \pm 0.58 \mathrm{mg} / \mathrm{L}(\mathrm{WAC} / \mathrm{III} / \mathrm{B} / 002)$; Carbonate $\mathrm{CO}_{3}<$ $6 \mathrm{mg} / \mathrm{L} \quad$ (WAC/III/A/006); Bicarbonate $\mathrm{HCO}_{3}: 689.67 \pm$ $232.19 \mathrm{mg} / \mathrm{L}$ (WAC/III/A/006); Mg: $24.33 \pm 2.31 \mathrm{mg} / \mathrm{L}$ (WAC/ III/B/002); Ca: $101 \pm 7.94$ mg/L (WAC/III/B/002); K: $146.67 \pm$ $11.59 \mathrm{mg} / \mathrm{L}$ (WAC/III/B/002); Na: $44 \pm 6.24 \mathrm{mg} / \mathrm{L}$ (WAC/III/ $\mathrm{B} / 002$ ); Total hardness as $\mathrm{CaCO}_{3}: 352.4 \pm 29.25 \mathrm{mg} / \mathrm{L}$ (WAC/III/ $\mathrm{A} / 009) ; \mathrm{SO}_{2}<10 \mathrm{mg} / \mathrm{L}$ (SM00087); $\mathrm{Cl}^{-}: 59 \pm 0 \mathrm{mg} / \mathrm{L}$ (WAC/III/ $\mathrm{C} / 001) ; \mathrm{S}^{2-}: 3.77 \pm 3.35 \mathrm{mg} / \mathrm{L}(\mathrm{SM} 00502) ; \mathrm{SO}_{4}{ }^{2-}: 28.3 \pm 46.51 \mathrm{mg} /$ $\mathrm{L}(\mathrm{WAC} / \mathrm{III} / \mathrm{C} / 00) ; \mathrm{PO}_{4}{ }^{3-}: 21 \pm 4.36 \mathrm{mg} / \mathrm{L}$ (WAC/III/C/001); $\mathrm{NO}_{2}{ }^{-}<0.020 \mathrm{mg} / \mathrm{L}(\mathrm{WAC} / \mathrm{III} / \mathrm{C}) ; \mathrm{NO}_{3}{ }^{-}<0.10 \mathrm{mg} / \mathrm{L}$ (WAC/ III/C/001); Fe: $2.37 \pm 0.29 \mathrm{mg} / \mathrm{L}$ (WAC/III/B/002), and Cu: $0.28 \pm$ $0.10 \mathrm{mg} / \mathrm{L}$ (WAC/III/B/002). The abundance of other heavy metals was measured at the onset of the experiment (following protocol WAC/III/B/002): Cd: $0.0004 \mathrm{mg} / \mathrm{L}, \mathrm{Pb}: 0.0027 \mathrm{mg} / \mathrm{L}, \mathrm{Zn}$ : $1.20 \mathrm{mg} / \mathrm{L}$, As: $0.0016 \mathrm{mg} / \mathrm{L}, \mathrm{Cr}: 0.011 \mathrm{mg} / \mathrm{L}, \mathrm{Ni}: 0.012 \mathrm{mg} / \mathrm{L}$, and $\mathrm{Hg}:<0.001 \mathrm{mg} / \mathrm{L}$.

Two weeks before the onset of the experiments, poultry wastewater was obtained from a local poultry farming research center (Proefbedrijf Pluimveehouderij VZW, Geel, Belgium). To remove solid particles, the wastewater was allowed to settle overnight and the supernatant was collected. This was stored for two weeks in dark conditions at $22^{\circ} \mathrm{C}$ until being used as wastewater medium. For sterile experimental conditions, the wastewater medium was autoclaved at $121^{\circ} \mathrm{C}(100 \mathrm{kPa})$ for $15 \mathrm{~min}$ and then allowed to gradually cool one day before use.

\section{Preparation of Experimental Media}

Sterile fresh or brackish culture medium (see Microalgal Strains and Stock Culture Conditions) was used as control medium in the outlined experiments below (see Pre-Screening the Growth Potential of Microalgal Strains, Chlorella sorokiniana growth on poultry wastewater and Analytical Methods). Wastewater medium dilutions were made by mixing it with the respective control media to the desired percentage one day before use (see Pre-Screening the Growth Potential of Microalgal Strains and Chlorella sorokiniana growth on poultry wastewater).

\section{Pre-Screening the Growth Potential of Microalgal Strains}

A. obliquus, C. sorokiniana, C. vulgaris, D. armatus, M. gaditana, and $P$. kessleri were selected for their reported applicability in microalgal technology (Hamed, 2016; Mobin and Alam, 2017), and screened for their ability to grow on poultry wastewater. Following experimental conditions were considered: $100 \%$ poultry wastewater (sterile and non-sterile), $100 \%$ fresh- or brackish medium (sterile), 50\% poultry wastewater diluted with fresh- or brackish medium (sterile), and 50\% poultry wastewater diluted with tap water (sterile, Supplementary Table S1) (Figure 1). Each experimental condition was duplicated.

At the onset of the screening experiment, inoculum $\left(\mathrm{OD}_{720} \sim 2.5\right)$ was added to the respective culture media till a starting concentration of $\mathrm{OD}_{720}=0.1$. Cultures were grown for 12-18 days in $250 \mathrm{ml}$-erlenmeyers under the same conditions as the inoculum cultures (see Microalgal Strains and Stock Culture Conditions). Culture growth was monitored 2-3 times per week (on Monday, Wednesday and Friday between 10.00 and 12.00 am, i.e., 2-4 h after turning on the lights) by optical density measurements (specifications in Determination of Microalgal Growth).

\section{Chlorella sorokiniana Growth on Poultry Wastewater}

Based on the pre-screening experiment, we selected one promising strain for further in-depth experimentation. Although also other strains were tolerant to wastewater culturing (see Pre-Screening the Growth Potential of Microalgal Strains), C. sorokiniana reached the highest optical density in wastewater conditions at the end of the growing period compared to the other strains. Moreover, C. sorokiniana is easy to cultivate and is widely used for diverse feedstock production, and was therefore selected as an attractive species for cultivation on wastewater (Ievina and Romagnoli, 2020; Slompo et al., 2020).

C. sorokiniana was cultured in either of the following nine conditions (Figure 2): 100, 75 and 50\% wastewater, both sterilized as well as non-sterilized. Dilutions were made with freshwater medium, which was also included as a control condition (sterile). In addition, the 50\% wastewater conditions were replicated with tap water as dilution medium (sterile and non-sterile). Each experimental condition was replicated three times. 


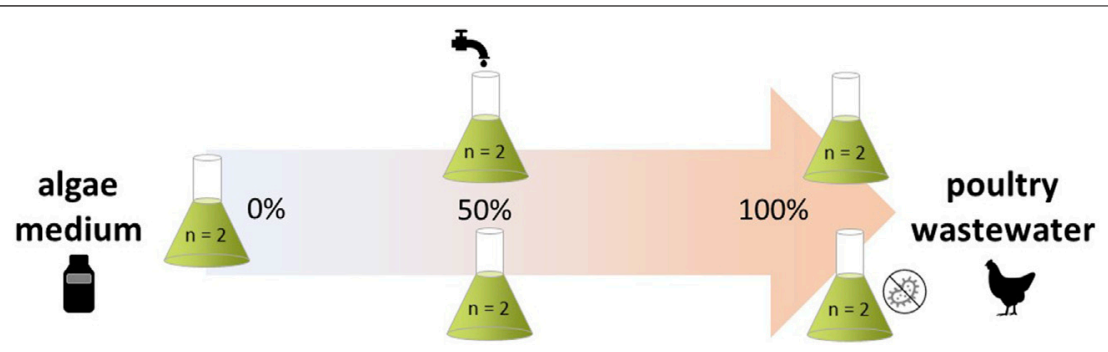

FIGURE 1 | Experimental setup to screen the microalgal growth potential on poultry wastewater dilutions. Microalgae were cultured on 100\% (sterile and nonsterile) or 50\% poultry wastewater (sterile), diluted either with freshwater (A. obliquus, C. sorokiniana, C. vulgaris, D. armatus, $P$. kessleri) or brackish water (M. gaditana) medium, or with tap water (all strains). 100\% fresh/brackish medium (sterile) was included as control. All conditions were duplicated.

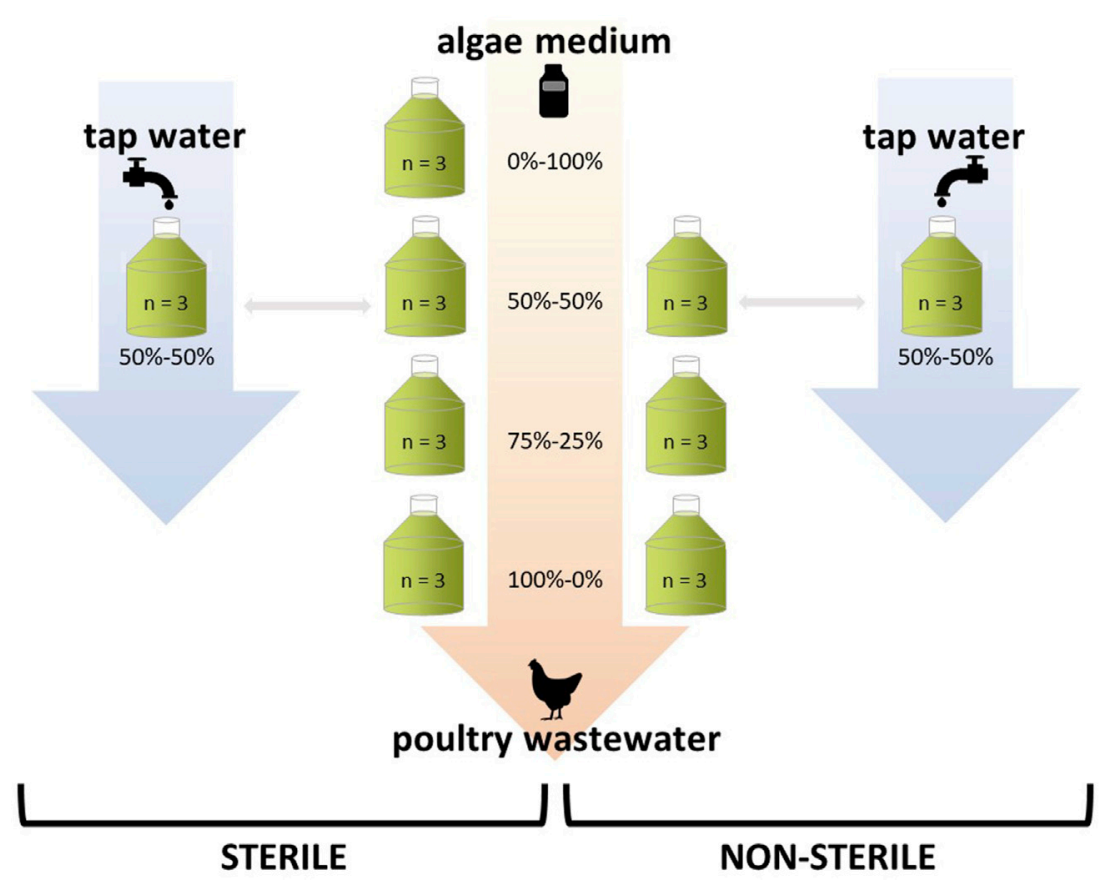

FIGURE 2 | Experimental setup to assess C. sorokiniana growth on non-/sterilized wastewater dilutions. Algae were cultured on 100, 75, 50 and 0\% (control) wastewater. Dilutions were made with freshwater medium, or with tap water (for the $50 \%$ wastewater treatment). All wastewater conditions were either sterilized or nonsterilized. Each experimental condition was replicated three times.

Similar to the screening experiment, inoculum $\left(\mathrm{OD}_{720} \sim 2.5\right)$ was added to the respective culture media till a starting concentration of $\mathrm{OD}_{720}=0.1$ at the onset of the experiment. Cultures were grown for 22 days in aerated glass $1 \mathrm{~L}$-bottles (to mix the cultures) under the same conditions as the inoculum cultures (see Microalgal Strains and Stock Culture Conditions). Culture growth was monitored 3 times per week (every Monday, Wednesday and Friday between 10.00 and 12.00am, i.e., 2-4 h after turning on the lights) by optical density (starting from day 0 ), cell count (starting from day 2) and dry weight measurements (starting from day 5) (specifications in Determination of Microalgal Growth). On these moments, also $\mathrm{pH}$ of the cultures was measured. Moreover, nutrient concentration and abundance of major pathogen groups (specifications in Pathogen
Removal) in the different cultures was assessed at the beginning and end of the experiment.

To ensure sufficient culture volume for quantitative analysis of macronutrient content and potential accumulation of heavy metals in C. sorokiniana biomass, an additional batch was cultured in aerated glass $2 \mathrm{~L}$-bottles for a total of $\sim 20 \mathrm{~L}$, following the protocols as described above (see Microalgal Strains and Stock Culture Conditions, Preparation of Culture Media and Chlorella sorokiniana growth on poultry wastewater). For these analyses, algae were grown on $50 \%$ non-sterilized wastewater diluted with tap water as a promising condition that supports $C$. sorokiniana growth (see Results). After 29 days of growth, samples were collected for analysis of heavy metal accumulation in the biomass, as well as for 
Weende- and amino acid analysis to determine the nutritional content of the biomass (specifications in Heavy Metal Accumulation and Macronutrient Content of the Microalgal Biomass).

\section{Analytical Methods}

\section{Determination of Microalgal Growth}

Three complementary techniques were used to monitor microalgal growth, following standard methods (Rice et al., 2017). 1) Optical density (OD) measurements were done at a wavelength of $720 \mathrm{~nm}$ on a spectrophotometer (Genesys 10S UVVIS, Thermo Fisher ScientificTM) using the respective media without microalgae as blank. 2) Cell counts were done using a microscope (DM50, Leica) and a Bürker counting chamber. 3) Samples ( $5 \mathrm{ml} / \mathrm{sample}$ ) to assess dry weight were filtered on glass microfiber membranes $(0.45 \mu \mathrm{m}$, washed in deionized water $)$, dried at $70^{\circ} \mathrm{C}$ for $24 \mathrm{~h}$ and transferred to a desiccator before weighing.

\section{Determination of Water Chemistry}

$\mathrm{pH}$ of the cultures was measured using a $\mathrm{pH}$ meter (Edge meter, Hanna Instruments). Microalgal nutrient usage was evaluated as the difference in $\mathrm{NaHCO}_{3}, \mathrm{NH}_{4}{ }^{+} \mathrm{N}, \mathrm{NO}_{3}{ }^{-}$, and $\mathrm{PO}_{4}{ }^{3-}$ concentration in the medium at the start compared to the end of the experiment. Per sampling event and per culture, $50 \mathrm{ml}$ samples were taken and stored at $4^{\circ} \mathrm{C}$. Prior to nutrient analysis, samples were centrifuged for $10 \mathrm{~min}$ at $1,550 \mathrm{~g}$ at $20^{\circ} \mathrm{C}$ (centrifuge Sorvall lynx 4000, Thermo Fisher Scientific).

Nitrate and phosphate content was determined by ionic chromatography (Metrohm Eco IC using a Metrosep A Supp $17-250 / 4.0$ column) and a $6 \mathrm{mM} \mathrm{Na}_{2} \mathrm{CO}_{3}$ buffer. Samples were pretreated by filtrating through 0.45 and $0.20 \mu \mathrm{m}$ disposable PETfilters (NBN EN ISO 10304-1).

Ammoniacal nitrogen content was determined by steam distillation (Vapodest 200, Gerhardt). To this end, each sample was diluted in a phosphate-buffer. Ammonia was expulsed from this weak alkaline solution by distillation ( $4 \mathrm{~min}, 100 \%$ steam power). Subsequently, ammonia was collected in a $2 \%$ boric acid solution and volumetrically determined by titration with $0.01 \mathrm{~N}$ HCl [CMA/2/I/E.3 (ISO 5664:1984)].

A titrimetric method (according to ISO 9963-1:1994) was used to determine the (bi)carbonate content. $\mathrm{HCO}_{3}{ }^{-} / \mathrm{CO}_{3}{ }^{2-}$ was titrated with a $0.01 \mathrm{~N} \mathrm{HCl}$ solution by an automatic titrator (DL50, Mettler Toledo).

\section{Pathogen Removal}

Abundance of major pathogen groups in the different culture media was determined at the onset (i.e., before algal inoculation) and the end of the experiment (i.e., after 3 weeks of algae growth). To this end, samples were collected per culture, and tested for abundance of Escherichia coli (WAC/V/A/002), Enterococcus sp. (WAC/V/A/003), Salmonella sp. (WAC/V/A/004), Campylobacter sp. (Microval MV2008LR12), Enterobacteriaceae (AFNOR BRD 7/24-11/13), coagulasepositive staphylococci (SM00457), sulfite-reducing anaerobes (ISO 6461-2) and Fungi (SM00318) using accredited methods for determining the number of colony forming units (CFU).
These pathogen groups were selected based on the microbiological safety norms for feed production as determined by the EU directive 183/2005/EC. Microbiological analyses were done by LOVAP NV (Geel, Belgium).

\section{Heavy Metal Accumulation and Macronutrient Content of the Microalgal Biomass}

C. sorokiniana was grown for 29 days in $50 \%$ unsterilized wastewater medium diluted with tap water to provide $\sim 20 \mathrm{~L}$ of sample culture for analysis of heavy metal accumulation in the biomass and macronutrient content. Samples were centrifuged at $1,550 \mathrm{~g}$ for $10 \mathrm{~min}$ to separate the biomass ( 120 $\mathrm{g}$ algae paste) from the liquid extract, and analyzed for abundance of $\mathrm{Fe}, \mathrm{Cu}, \mathrm{Cd}$, $\mathrm{Pb}, \mathrm{Zn}, \mathrm{As}, \mathrm{Cr}, \mathrm{Ni}$ and $\mathrm{Hg}$ using ICP-MS (protocol SM01571 for $\mathrm{Hg}$, SM00448 for others). Weende analysis was used to determine the macronutrient content, specifically moisture content (ISO 1442), inorganic substance (mineral fraction, ISO 936), crude protein level $(\mathrm{N}$-containing substance $\times 6.25$ following ISO 1871 , including amino acid content using protocol SM00305 (CS)), raw fat content (ISO 1443), crude fiber content (SM00121), starch content (Ewers method SM00120) and abundance of total carbohydrates (SM00093, calculated). All analyses were done by LOVAP NV (Geel, Belgium) following accredited methods.

\section{Statistical Analysis}

All statistical analyses were performed in $\mathrm{R}$ version 4.0.2 ( $\mathrm{R}$ Development Core Team, 2008) at a 0.05 significance level. Model assumptions were verified graphically for all analyses.

All measures of $C$. sorokiniana growth $\left(\mathrm{OD}_{720}\right.$, cell count, dry weight measurement) were analyzed using mixed modelling with Gaussian error distribution (lme4 package; Bates et al., 2017). To assess average differences in biomass density over time, condition (referring to all experimental conditions, as in Figure 2) and time (referring to the repeated measures over time) were added as fixed factors. Culture identity was added as a random effect to account for between- and within-culture variation over time. To more directly assess the impact of wastewater dilution and-sterilization on C. sorokiniana growth, a second mixed model was used (for all OD, cell count and dry weight measures) with dilution-treatment $(100,75,50 \%)$ and sterilizationtreatment (sterilized, non-sterilized) as fixed factors, including their full interaction. Time and culture identity were added as an additional fixed factor and random effect, respectively. Significance of the fixed effects in the mixed models was tested with Type III Wald chi-square tests. Post-hoc differences were assessed by means of Tukey-corrected pairwise comparisons (lsmeans package; Lenth and Love, 2017).

\section{RESULTS}

\section{Pre-Screening the Growth Potential of Microalgal Strains}

In contrast to M. gaditana, both C. sorokiniana and C. vulgaris showed reasonable tolerance and ability to grow on poultry wastewater dilutions. For instance, no growth was observed for M. gaditana in any wastewater condition, while C. sorokiniana 

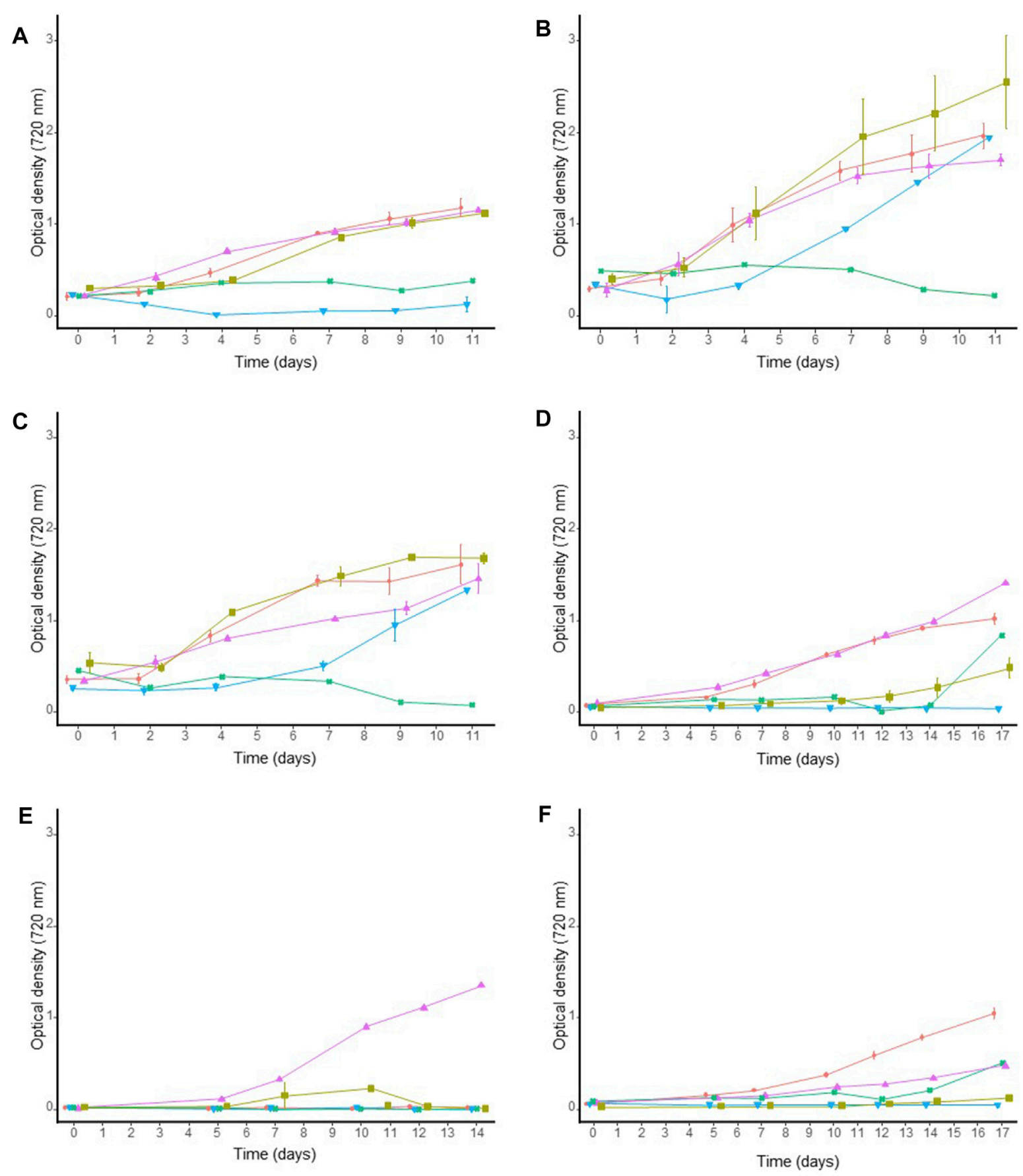

$-0 \%$ wastewater $(100 \%$ control medium $)-50 \%$ wastewater + control medium $-50 \%$ wastewater + tap water

$\because-100 \%$ wastewater (non-sterile) $\quad \longrightarrow-100 \%$ wastewater (sterile)

FIGURE 3 | Growth curves (based on optical density) of microalgal strains on poultry wastewater dilutions. Culture growth was monitored for 12-18 days through optical density $(720 \mathrm{~nm})$ measurements for (A) A. obliquus, (B) C. sorokiniana, (C) C. vulgaris, (D) D. armatus, (E) M. gaditana and (F) P. kessleri. The results are given as the average of two values, and whiskers delineate the standard deviation. 


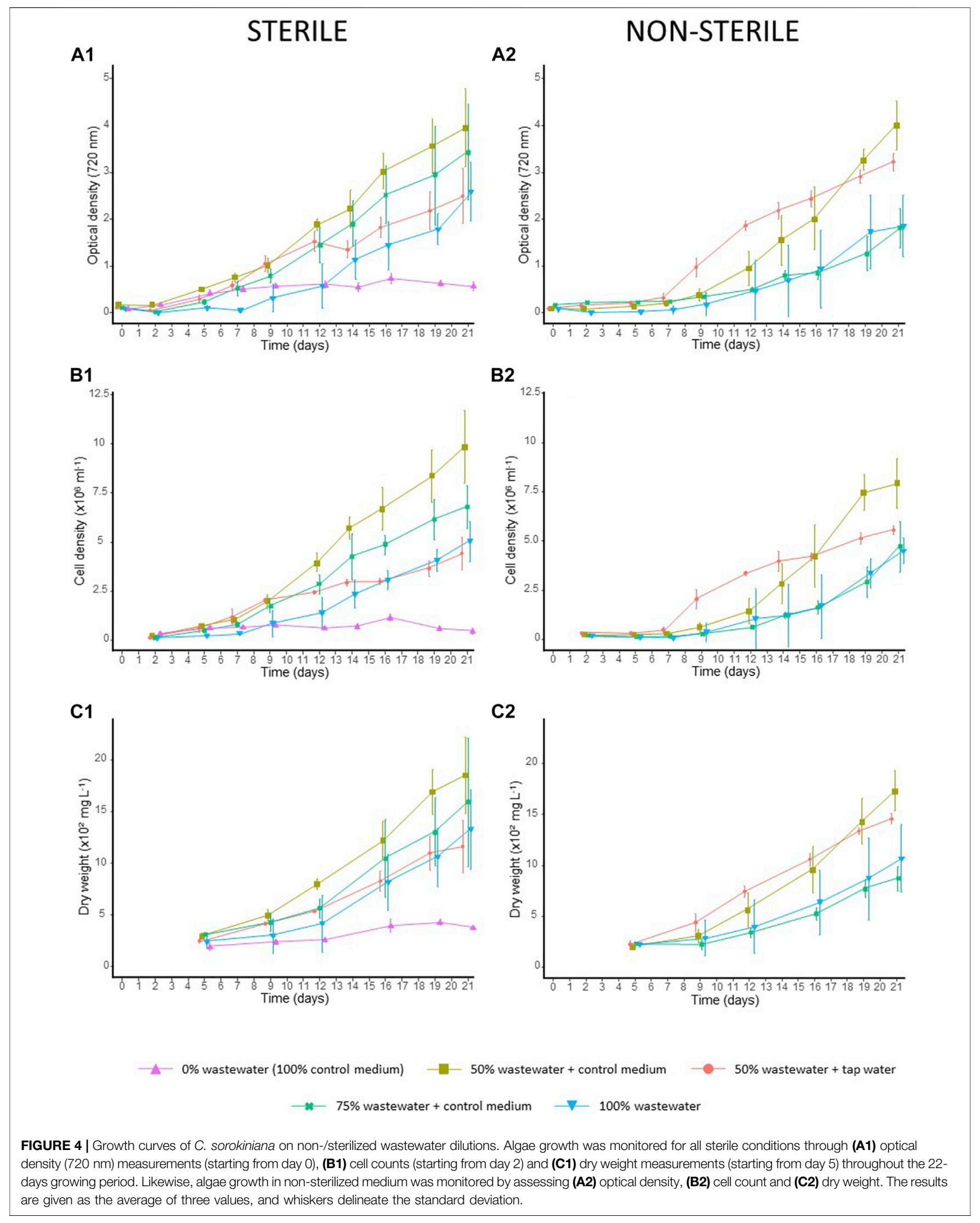


TABLE 1 | Model output to assess average differences in biomass density over time. (Treatment: 100, 75 or $50 \%$ wastewater; Sterile: sterilized or non-sterilized; Time: repeated measures over time; see Statistical Analysis).

\begin{tabular}{|c|c|c|c|c|c|c|}
\hline \multirow[b]{2}{*}{ Effect } & \multicolumn{2}{|c|}{ Optical density (720 nm) } & \multicolumn{2}{|c|}{ Cell count } & \multicolumn{2}{|c|}{ Dry weight } \\
\hline & $\chi^{2}$ & $p$-value & $\chi^{2}$ & $p$-value & $\chi^{2}$ & $p$-value \\
\hline Treatment & 33.788 & $<0.001$ & 56.818 & $<0.001$ & 13.878 & 0.003 \\
\hline Sterile & 7.760 & 0.005 & 20.031 & $\overline{<0.001}$ & 3.792 & $\overline{0.051}$ \\
\hline Time & $1,195.696$ & $\overline{<0.001}$ & 907.954 & $\overline{<0.001}$ & 833.054 & $<0.001$ \\
\hline Treatment*Sterile & 13.794 & $\overline{0.003}$ & 25.348 & $\overline{<0.001}$ & 8.306 & 0.040 \\
\hline
\end{tabular}

$p$-values $<0.05$ are shown in bold and underlined.

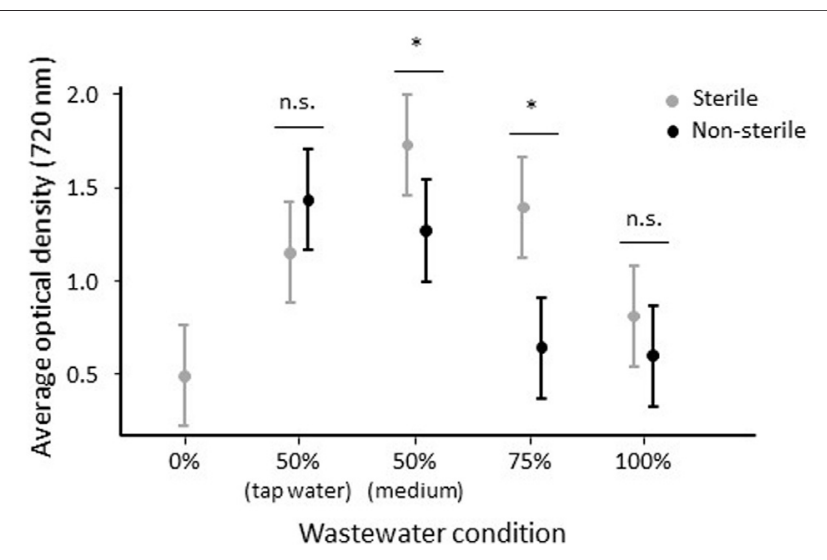

FIGURE 5 | Average optical density $(720 \mathrm{~nm})$ of $C$. sorokiniana cultures in relation to wastewater dilution and medium sterilization. Whiskers delineate the upper and lower 95\% confidence limit. Non-/significant differences are based on Tukey-corrected post-hoc tests and are indicated with n.s or an asterisk $\left({ }^{\star}\right)$, respectively.

and C. vulgaris reached $\mathrm{OD}_{720}=2.55( \pm 0.51 \mathrm{SD})$ and $\mathrm{OD}_{720}=$ $1.68( \pm 0.06 \mathrm{SD})$ after 11 days of growth on $50 \%$ diluted wastewater (diluted with control medium), respectively (Figure 3). A. obliquus, D. armatus and P. kessleri performed intermediately on diluted wastewater, with a maximum density at the end of the screening of $\mathrm{OD}_{720}=1.18( \pm 0.10 \mathrm{SD}), \mathrm{OD}_{720}=1.02$ $( \pm 0.05 \mathrm{SD})$ and $\mathrm{OD}_{720}=1.05( \pm 0.06 \mathrm{SD})$, respectively (Figure 3). Based on the results of this screening, C. sorokiniana was selected for a more-detailed follow-up experiment.

\section{Chlorella sorokiniana Growth on Non-/Sterilized Wastewater Dilutions}

Overall mean biomass production of C. sorokiniana was 47.841 ( $\pm 55.403 \mathrm{SD}) \mathrm{mg} \mathrm{L}^{-1} \mathrm{day}^{-1}$, with a mean biomass of 1.271 $( \pm 0.515 \mathrm{SD}) \mathrm{g} \mathrm{L}^{-1}$ at the end of the experiment. Still, biomass productivity differed between conditions, as confirmed by monitoring of optical density $\left(720 \mathrm{~nm}: \chi^{2}=81.532 ; \boldsymbol{p}<\right.$ $0.001)$, cell count $\left(\chi^{2}=166.090 ; \boldsymbol{p}<0.001\right)$ and dry weight $\left(\chi^{2}\right.$ $=51.630 ; \boldsymbol{p}<0.001$ ) (Figures 4A-C). A maximum biomass of $1.853( \pm 0.371 \mathrm{SD}) \mathrm{gL}^{-1}$ was reached by the end of the experiment for C. sorokiniana grown in sterile $50 \%$ wastewater diluted with control medium (averaged over three values) (Figure 4C1).
Based on average optical density $(720 \mathrm{~nm})$ difference over time, medium sterilization supported an overall $29 \%$ increase in microalgal growth. Likewise, wastewater dilution overall facilitated microalgal growth, with a productivity increase of 113 and $83 \%$ when wastewater was diluted for 50\% with freshwater medium and tap water, respectively (averaged over sterile and non-sterile conditions). Still, the effect of medium sterilization and wastewater dilution on average biomass density were dependent on each other (Table 1). More specifically, wastewater sterilization enhanced algal growth with $36-118 \%$, but only when wastewater was 25-50\% diluted with standard medium (Figure 5). In contrast, sterilization had no (additional) beneficial effects if wastewater was either not diluted or diluted with $50 \%$ tap water (Figure 5). These effects of medium sterilization and wastewater dilution, including their interactive effects, were corroborated by the results for cell count and dry weight (Table 1).

\section{pH of the Growth Media, and Nutrient- and Pathogen Removal}

Apart from sterilized wastewater dilutions, $\mathrm{pH}$ of all growth media showed an upward trend over time starting from $\mathrm{pH}=$ $7.62( \pm 0.17 \mathrm{SD})$ and increasing to $\mathrm{pH}=9.30( \pm 0.36 \mathrm{SD})$ by the end of the experiment (Figure 6). The initial $\mathrm{pH}$ of sterilized wastewater dilutions was higher than that of other conditions (mean 9.54 \pm SD 0.08) and remained relatively constant over time (Figure 6).

Average concentrations of $\mathrm{NaHCO}_{3}$ at the onset of the experiment for sterile conditions (mean $0.519 \pm$ SD $0.156 \mathrm{~g}$ $\mathrm{L}^{-1}$ ) increased with $41 \%$ throughout the experiment to 0.732 $( \pm 0.210 \mathrm{SD}) \mathrm{g} \mathrm{L}^{-1}$. In contrast, average $\mathrm{NaHCO}_{3}$ concentrations in non-sterilized wastewater dilutions decreased with $44 \%$ from $1.193( \pm 0.320 \mathrm{SD}) \mathrm{g} \mathrm{L}^{-1}$ to $0.667( \pm 0.134 \mathrm{SD}) \mathrm{g} \mathrm{L}^{-1}$ (Table 2).

A $100 \%$ removal was attained for $\mathrm{NH}_{4}{ }^{+}-\mathrm{N}$ for all conditions. Similarly, and although there was notable variation in starting concentration between the different conditions (Table 2), $\mathrm{NO}_{3}{ }^{-}$ decreased in all conditions with $47-100 \%$.

Starting $\mathrm{PO}_{4}{ }^{3-}$ concentrations (mean $5.447 \pm \mathrm{SD} 2.032 \mathrm{mg} \mathrm{L}^{-1}$ ) in sterilized wastewater dilutions were low and increased with an average of $81 \%$ by the end of the experiment (mean $9.847 \pm$ SD $3.255 \mathrm{~g} \mathrm{~L}^{-1}$ ). In contrast, the $\mathrm{PO}_{4}{ }^{3-}$ starting concentrations of control medium and non-sterilized wastewater dilutions (mean 


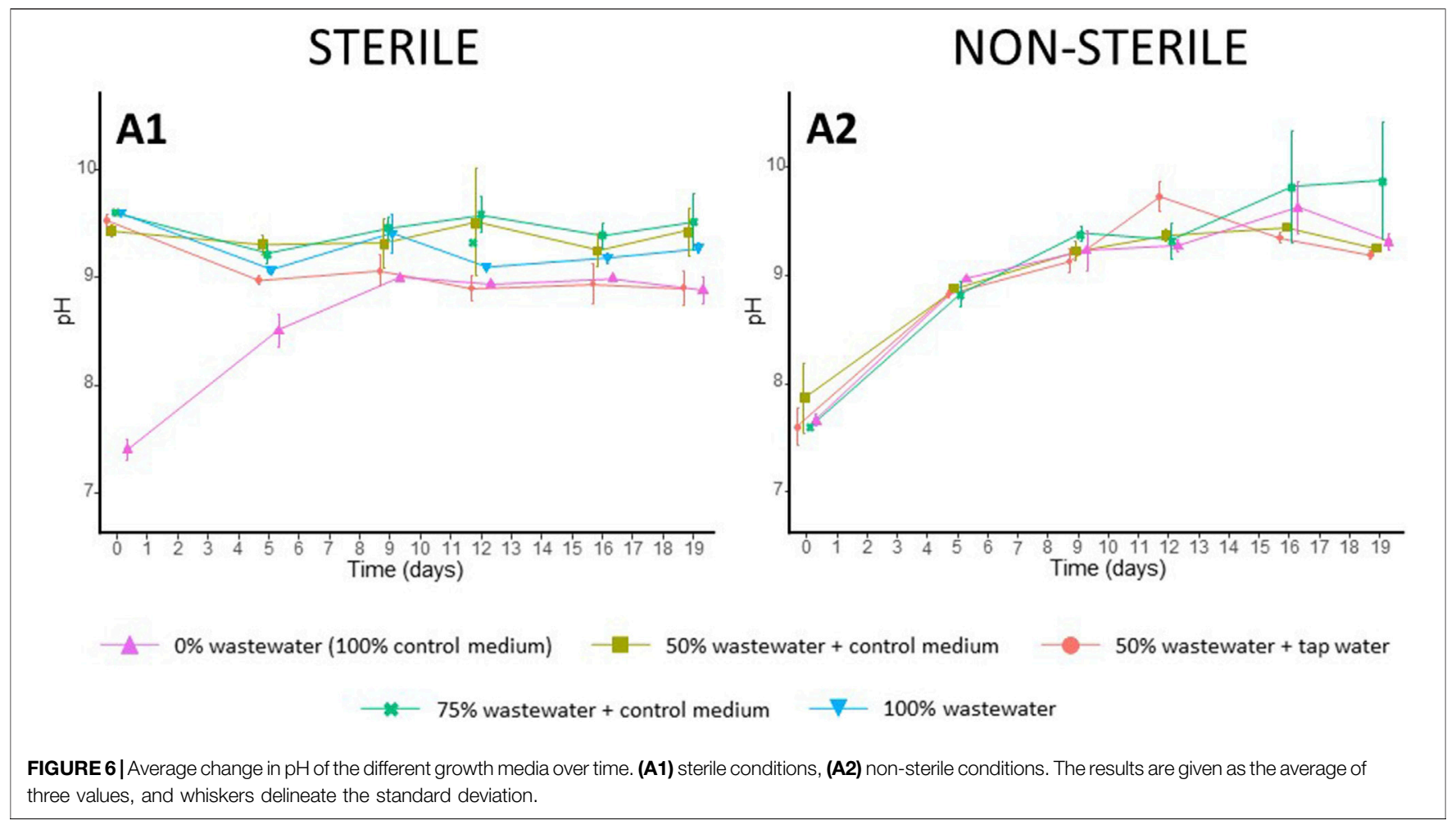

TABLE 2 Nutrient concentrations in the different growth media at the beginning and end of the experiment. Mean concentration, standard deviation (SD, $n=3$ ) and average percentual change (\%) between start- and end-concentration is given for $\mathrm{NaHCO}_{3}\left(\mathrm{~g} \mathrm{~L}^{-1}\right), \mathrm{NH}_{4}{ }^{+}-\mathrm{N}\left(\mathrm{mg} \mathrm{L}^{-1}\right), \mathrm{NO}_{3}{ }^{-}\left(\mathrm{g} \mathrm{L}^{-1}\right)$ and $\mathrm{PO}_{4}{ }^{3-}\left(\mathrm{mg} \mathrm{L}^{-1}\right)$.

\begin{tabular}{|c|c|c|c|c|c|c|c|c|c|c|c|c|c|}
\hline & & \multicolumn{3}{|c|}{$\mathrm{NaHCO}_{3}$} & \multicolumn{3}{|c|}{$\mathrm{NH}_{4}{ }^{+}-\mathrm{N}$} & \multicolumn{3}{|c|}{$\mathrm{NO}_{3}^{-}$} & \multicolumn{3}{|c|}{$\mathrm{PO}_{4}{ }^{3-}$} \\
\hline & & Mean & SD & $\%$ & Mean & SD & $\%$ & Mean & SD & $\%$ & Mean & SD & $\%$ \\
\hline \multicolumn{14}{|l|}{ Sterile conditions } \\
\hline $0 \%$ wastewater & End & 0.627 & 0.064 & $+109 \%$ & 0 & 0 & $-100 \%$ & 159.630 & 30.105 & $-47 \%$ & 12.417 & 1.135 & $-57 \%$ \\
\hline \multirow[t]{2}{*}{$50 \%$ wastewater + control } & Start & 0.537 & 0.040 & & 38.333 & 2.08 & & 182.350 & 7.397 & & 4.777 & 0.232 & \\
\hline & End & 0.827 & 0.273 & $+54 \%$ & 0 & 0 & $-100 \%$ & 0.097 & 0.040 & $-99.9 \%$ & 11.637 & 1.664 & $+144 \%$ \\
\hline \multirow[t]{2}{*}{$75 \%$ wastewater + control } & Start & 0.573 & 0.093 & & 58.667 & 4.933 & & 79.750 & 4.060 & & 8.217 & 0.385 & \\
\hline & End & 0.747 & 0.240 & $+30 \%$ & 0 & 0 & $-100 \%$ & 0.123 & 0.092 & $-99.8 \%$ & 7.273 & 1.521 & $+11 \%$ \\
\hline \multirow[t]{2}{*}{$100 \%$ wastewater } & Start & 0.747 & 0.042 & & 84.667 & 2.309 & & 0.747 & 0.491 & & 3.013 & 0.931 & \\
\hline & End & 0.923 & 0.138 & $+24 \%$ & 0 & 0 & $-100 \%$ & 0.140 & 0.020 & $-81 \%$ & 12.700 & 3.394 & $+322 \%$ \\
\hline \multicolumn{14}{|l|}{ Non-sterile conditions } \\
\hline \multirow[t]{2}{*}{$50 \%$ wastewater + control } & Start & 0.967 & 0.011 & & 65.333 & 1.527 & & 74.593 & 16.939 & & 33.347 & 4.928 & \\
\hline & End & 0.76 & 0.128 & $-24 \%$ & 0 & 0 & $-100 \%$ & 0 & 0 & $-100 \%$ & 11.983 & 2.043 & $-64 \%$ \\
\hline \multirow[t]{2}{*}{$100 \%$ wastewater } & Start & 1.636 & 0.029 & & 139.667 & 2.517 & & 0.597 & 0.362 & & 39.283 & 9.573 & \\
\hline & End & 0.777 & 0.080 & $-52 \%$ & 0 & 0 & $-100 \%$ & 0.023 & 0.040 & $-96 \%$ & 12.187 & 3.500 & $-69 \%$ \\
\hline
\end{tabular}

$\left.33.394 \pm \mathrm{SD} 6.503 \mathrm{~g} \mathrm{~L}^{-1}\right)$ were higher and decreased with an average of $50 \%$ (mean $16.817 \pm 7.157 \mathrm{~g} \mathrm{~L}^{-1}$ ) (Table 2).

The abundance of major pathogen groups in $100 \%$ wastewater was either increased (Enterococcus sp., sulfite-reducing anaerobes, coagulase-positive staphylococci and Campylobacter sp.) or decreased (E. coli, Enterobacteriaceae, and Fungi) by the end of the experiment (Table 3). In contrast, when wastewater was diluted, the tested pathogens (except for coagulase-positive staphylocolli and Campylobacter sp.) were diminished at the end of the experiment (Table 3). 
TABLE 3 | Abundance of major pathogen groups per experimental condition (non-sterilized wastewater dilutions 50-100\%) at the onset and end of the experiment. Values are expressed as CFU per $100 \mathrm{ml}$.

\begin{tabular}{|c|c|c|c|c|c|}
\hline & \multirow{2}{*}{$\frac{\text { Onset }}{100 \%}$} & \multicolumn{4}{|c|}{ End } \\
\hline & & $100 \%$ & $75 \%$ & $50 \%$ (medium) & $50 \%$ (tap water) \\
\hline Escherichia coli & $>1,000$ & $<100$ & $<100$ & $<100$ & $<100$ \\
\hline Enterococcus sp. & 460 & 2,000 & 300 & $<100$ & $<100$ \\
\hline Salmonella sp. & $0^{\mathrm{a}}$ & 0 & 0 & 0 & 0 \\
\hline Enterobacteriaceae & $>1,000$ & 400 & 300 & 500 & $<100$ \\
\hline Sulfite-reducing anaerobes & $>1,000$ & 31,000 & $<100$ & 500 & $<100$ \\
\hline Fungi & $>1,000$ & 2 & $<1$ & 3 & 4 \\
\hline Coagulase-positive staphylococi & $<1$ & $<100$ & $<100$ & $<100$ & $<100$ \\
\hline Campylobacter sp. & $<1$ & $<100$ & $<100$ & $<100$ & $<100$ \\
\hline
\end{tabular}

${ }^{a}$ CFU per $1 \mathrm{~L}$

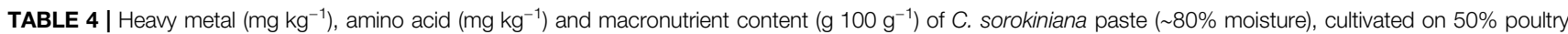
wastewater diluted with tap water. Macronutrient content in algae paste was extrapolated to relative abundance in dry mass (assuming a $5 \%$ moisture level).

\begin{tabular}{|c|c|c|c|c|c|c|}
\hline \multirow{2}{*}{\multicolumn{2}{|c|}{$\frac{\text { Algae paste }}{\text { Heavy metals }}$}} & \multicolumn{2}{|l|}{ Algae } & \multirow{2}{*}{ Macronutrients } & \multirow{2}{*}{ Algae paste } & \multirow{2}{*}{ Dry mass } \\
\hline & & Amino acids & & & & \\
\hline $\mathrm{Fe}$ & 173 & Threonine + Arginine & 5,160 & Moisture & 79.8 & $\sim 5$ \\
\hline $\mathrm{Cu}$ & 21 & Aspartic acid & 4,150 & Inorganic substance & 2.23 & $\sim 9$ \\
\hline $\mathrm{Cd}$ & 0.037 & Glutamic acid & 4,380 & Total protein & 4.90 & $\sim 20$ \\
\hline $\mathrm{Pb}$ & 0.33 & Serine & 1,750 & Starch & 4 & $\sim 16$ \\
\hline $\mathrm{Zn}$ & 101 & Histidine & 795 & Crude fiber & 0.49 & $\sim 2$ \\
\hline As & 0.12 & Glycine & 3,260 & Total fat & 4.2 & $\sim 17$ \\
\hline $\mathrm{Cr}$ & 0.62 & Alanine & 3,640 & Total carbohydrates & 8.8 & $\sim 35$ \\
\hline $\mathrm{Ni}$ & 0.39 & Gamma-Aminobutyric acid & 256 & & & \\
\hline \multirow[t]{8}{*}{$\mathrm{Hg}$} & 0.011 & Tyrosine & 1,040 & & & \\
\hline & & Valine & 2,640 & & & \\
\hline & & Methionine & 1,230 & & & \\
\hline & & Isoleucine & 2,460 & & & \\
\hline & & Phenylalanine & 3,680 & & & \\
\hline & & Leucine & 3,790 & & & \\
\hline & & Ornithine & 117 & & & \\
\hline & & Lysine & 2,500 & & & \\
\hline
\end{tabular}

\section{Heavy Metal and Macronutrient Content of the Microalgal Biomass}

The abundance of heavy metals in algae paste ( $\sim 80 \%$ moisture), as well as its amino acid and macronutrient content is given in Table 4.

\section{DISCUSSION}

Using wastewater as cultivation medium for microalgae may lower the economic and environmental costs of producing multifunctional feedstock but, ideally, a high biomass productivity and quality/safety is attained without the need for expensive pretreatment of wastewater. To explore the viability of this approach, it is important to have a better understanding of which wastewater conditions favor microalgal growth and how these affect the quality and safety of the produced biomass. We examined the growth of $C$. sorokiniana on poultry wastewater and found that dilution and sterilization of the wastewater enhances microalgal biomass production. Still, wastewater sterilization may not be strictly necessary because 1) it offered no additional benefits for microalgal growth when wastewater was diluted for $50 \%$ with tap water, and 2 ) major pathogen groups were reduced until below safety norms for feed production after algal growth in $50 \%$ diluted, unsterilized wastewater. These dilutions can be made without the strict need of additional nutrient supplementation. Moreover, the high quality (high macronutrient content) and safety (no deleterious accumulation of heavy metals) of the produced biomass opens the opportunity for multifunctional use of microalgal feedstock.

\section{Technical Challenges of Microalgae Cultivation in Wastewater}

Wastewater often needs pretreatment before it can be used successfully as algal growth medium, which determines to a large extent the feasibility of cultivating microalgae in wastewater on full scale (Alcántara et al., 2015; Guldhe et al., 2017). Such pretreatment depends on the source and strength of wastewater and on the system that is used to cultivate microalgae 
(Guldhe et al., 2017). Especially when using high strength wastewaters (i.e., large quantities of suspended solids) such as poultry wastewater under phototrophic conditions, high turbidity due to suspended solids may limit algal growth as it affects light scatter and penetration, and, consequently, reduces light availability (Ansari et al., 2017). Moreover, excess nutrient loading may inhibit microalgal growth rates (Markou, 2015). For instance, poultry litter typically has a high content of nitrogenous compounds and may lead to accumulation of ammonia in poultry wastewater to levels that are generally toxic to microalgae (Nahm, 2003; Peccia et al., 2013; Markou, 2015). Still, the detected levels in the current study were well below lethal concentrations for Chlorella sp. This microalgae genus is relatively resistant to high ammonium nitrogen levels, with reported $\mathrm{EC}_{50}$-values (concentration at which photosynthetic efficiency is reduced to $50 \%$ of its maximum rate) of $0.4-1.6 \mathrm{~g} \mathrm{~L}^{-1}$ (Wang et al., 2019). Nevertheless, coping successfully with high turbidity and nutrient toxicity of wastewaters often requires dilution (in combination with filtration to remove solids) prior to use as growth medium. Indeed, $50 \%$ dilution of wastewater with either control medium or tap water roughly doubled biomass productivity compared to when pure wastewater was used, which may be due to lower compound toxicity (e.g., ammonia toxicity) as well as due to lower turbidity and higher light availability to support algal growth. Similar results were reported for microalgae grown on other types of wastewater. For instance, C. sorokiniana could not grow on frigon wastewater (from silk industry) because of high salinity and turbidity, but high biomass production was reached when the wastewater was diluted (Deng et al., 2019). Likewise, biomass yield of $C$. vulgaris grown in diluted poultry litter leachate was higher compared to control cultures in standard medium, and peaked at the highest tested dilution factor (25x) (Markou et al., 2016).

Even though algal growth rates were dependent on the dilution rate, the observed growth curves also suggest that cultures may not have reached the full carrying capacity. Hence, we cannot exclude that, after an initial lag-phase, high algae biomass density may also be achieved in pure wastewater. Future studies should assess how this delay may affect the balance of economic viability and environmental sustainability of microalgae cultivation in wastewater. For instance, even though high productivity rates are imperative to keep operating costs down, this initial delay could still compensate for potential disadvantages of wastewater dilution. These mainly pertain to the increased water footprint compared to the use of pure wastewater (Guldhe et al., 2017), as well as to an over-dilution of essential nutrients such as $\mathrm{P}$ and $\mathrm{K}$ which may lead to nutrient limitation (Markou, 2015). The latter can be overcome by supplementing additional chemical nutrients, but this comes at an extra cost to microalgal cultivation (Guldhe et al., 2017). Dilution therefore needs to be optimized depending on the used microalgae strain, the cultivation system and the chemical composition of the wastewater, and should be tailored to local conditions. To this end, blending of wastewaters with different nutrient content offers interesting perspectives to meet the nutrient requirements while lowering the water footprint (Park et al., 2015).
Besides dilution, the most common pretreatments of wastewater are microfiltration and autoclaving to limit the growth of undesired organisms (Guldhe et al., 2017). Indeed, microbial load may negatively affect microalgal growth, and reduction or elimination of microorganisms from wastewater before use is often advised (Cho et al., 2011; Lian et al., 2018). Although autoclaving is generally the most efficient method to reduce the microbial load in wastewater, it may also change the water chemistry and potentially result in a less suitable growth medium for microalgae. For instance, as also suggested by the results of the current study, autoclaving may imbalance the bicarbonate buffer system and lead to an increased $\mathrm{pH}$, as well as reduce the loading of nutrients that are essential for microalgal growth (Sriram and Seenivasan, 2012). These results are corroborated by earlier studies, showing a $\mathrm{pH}$ increase and a reduction of ammonia $(-45 \%)$ and phosphate $(-7 \%)$ content after autoclaving (Ramsundar et al., 2017). Moreover, autoclaving is time- and energy-demanding and is therefore not suitable for use at commercial scale (Guldhe et al., 2017). While studies increasingly explore cost-effective alternatives such as membrane filtration (Cho et al., 2011), ozonation (Gan et al., 2014), ultraviolet treatment and chlorination (Qin et al., 2014), the current study suggests that it may not always be strictly necessary to sterilize wastewater. Upon $50 \%$ dilution with tap water, wastewater sterilization offered no major additional benefit for algal growth, suggesting that the microbial load did not negatively affect the growth of $C$. sorokiniana under these conditions. Given that bacteria and microalgae may compete for nutrients (Grover, 2000), a reduced competition for resources upon dilution of the microbial load likely underlies this result. An earlier study showed that bacteria and protozoa in effluent water from a municipal wastewater treatment plant inhibits the growth of Chlorella sp. (Cho et al., 2011). Likewise, microalgal growth rate was inhibited by various bacterial strains in Dunaliella cultures (Le Chevanton et al., 2013). Despite these findings, it should be noted that species-specific symbiotic relationships between microalgae and bacteria could occur that promote, rather than inhibit, the growth of microalgae (Higgins and VanderGheynst, 2014; Ramanan et al., 2016). For instance, studies report beneficial effects of Bacillus, Flavobacterium and Rhizobium species on $C$. vulgaris (Lian et al., 2018). If the need to sterilize wastewater before use could be omitted altogether, then this would further increase the cost-effectiveness of the process. Still, in contrast to when tap water is used as dilution medium, the results also show that sterilization positively affects algal growth when wastewater is diluted with control medium, suggesting that the need to combine multiple pretreatment steps should be evaluated on a case-by-case basis. In this context, it should be noted that also other microalgae species-such as A. obliquus, C. vulgaris and D. armatus-were relatively tolerant to $50 \%$ poultry wastewater dilution and may shift the balance of which pretreatment steps are strictly necessary. To shed further light on the necessity of pretreatment, in-depth studies are needed that map the microbial diversity and abundance under different wastewater conditions throughout the cultivation of microalgae. Relating such data to $\mathrm{pH}$ and nutrient levels will improve our understanding of how 
competing or predatory microorganisms interact with microalgae and affect algal biomass production.

\section{Wastewater-Derived Algal Biomass as Feedstock for Animal Feed}

Because of its high nutrient content, poultry sludge is traditionally applied to cropland as organic fertilizer (Patrinou et al., 2020). However, improper management can lead to accumulation of pollutants (e.g., heavy metals) in the environment, and nutrients may wash out and leach into adjacent aquatic systems (Asadi et al., 2019). The resulting eutrophication threatens the integrity of ecosystems, among others through instigating harmful algal blooms that impede ecosystem-functioning and services (Bhatia et al., 2020; Mohsenpour et al., 2021). To reduce the quantity of organic material and nutrients that are discharged into the environment, wastewater can first be treated through various physical and chemical methods (Bhatia et al., 2020; Mohsenpour et al., 2021). Still, classic water treatment is energy-intensive, consuming up to $2-4 \%$ of national electric power, and has a high environmental footprint (Bhatia et al., 2020; Zawartka et al., 2020). In recent years, bioremediation by microalgae emerged as an alternative to remove pollutants and nutrients from wastewater. In the current study, ammonium, nitrate and phosphate concentrations in unsterilized and undiluted wastewater were reduced by 100, 96 and 69\%, respectively, after 22 days of $C$. sorokiniana growth. Previous studies on $C$. sorokiniana show similar results, with nutrient removal efficiencies of $74-84 \%$ after 10 days of growth in municipal wastewater (Eladel et al., 2019), and 92-97\% removal after 24 days of growth in $50 \%$ diluted swine wastewater (Chen et al., 2020). In addition, this approach adds value to the water treatment process by the production of commercially valuable microalgal feedstock. This biomass production was associated with a concomitant increase in $\mathrm{pH}$ as a typical indicator of dissolved carbon uptake during photosynthesis (Chi et al., 2011; Hulatt and Thomas, 2011). Changes in $\mathrm{pH}$ are additionally governed by a range of intricately connected mechanisms that influence water chemistry. These include the release of photosynthetically fixed carbon from cells during respiration or decomposition, the rate of which may be exacerbated when algae experience stress such as nutrient depletion (Hulatt and Thomas, 2011). Also nutrient uptake may lead to changes in $\mathrm{pH}$, with assimilation of nitrate and ammonium typically increasing or decreasing $\mathrm{pH}$, respectively (Goldman and Brewer, 1980; Hulatt and Thomas, 2011). In part, such changes are mediated by the bicarbonate buffer system (Cole and Prairie, 2009).

Despite the mounting interest in this system, so far relatively little studies were conducted using poultry sludge (Markou, 2015; Patrinou et al., 2020). Moreover, produced biomass on wastewater is generally considered as feedstock for biofuel production only (Caporgno et al., 2015; Salama et al., 2017). To realize the full potential of wastewater-cultivated microalgae, it is crucial to combine and integrate green technologies (Clark, 2019). From this perspective, it is desirable to integrate biofuel production with other revenue streams including food and feed production (Rösch et al., 2019). However, this is currently difficult because not only should the quality and safety standards for the food/feed sector be met, but also consumer acceptance and current regulations are major bottlenecks. For instance, the different animal feed regulations of the EU (1831/ 2003, 767/2009 annex III and 178/2002) currently exclude the use of nutrients from manure or wastewaters from the production of animal feed additives, even after thorough treatment. While strong safety requirements are needed to prevent any risk of contamination in the animal feed chain, research is needed to evaluate whether or not a blanket exclusion of resource recycling from waste for food and feed applications is appropriate. The current study shows that the tested pathogen groups were reduced until below safety norms for feed production (EU directive 183/2005/EC) after 22 days of $C$. sorokiniana growth on $50 \%$ diluted wastewater (diluted with tap water). A similar reduction in pathogen abundance was shown for C. sorokiniana cultures on anaerobically treated black water, with a removal efficiency of $69 \%$ for total coliforms and $100 \%$ for E. coli (Slompo et al., 2020). In undiluted poultry wastewater, pathogen-dependent increases or decreases were observed by the end of the cultivation period. While our understanding of the interactions between pathogens and microalgae is still very limited, underlying mechanisms could include differences in nutrient competitiveness, different sensitivities to dissolved oxygen and $\mathrm{pH}$ changes, and the potential production of antibacterial metabolites (Slompo et al., 2020).

Besides pathogens, also heavy metal content of the biomass should be below safety norms. Microalgae have an abundance of extracellular binding sites and a large surface area that facilitates the adsorption and subsequent accumulation of heavy metals (Pradhan et al., 2019; Leong and Chang, 2020). This, combined with several detoxification mechanisms and a relatively high tolerance to heavy metal stress, makes microalgae useful to remediate toxic heavy metals from the environment (Leong and Chang, 2020). Still, the detected heavy metal content in concentrated biomass (algae paste) was below maximum limits as determined by the EU directive 2002/32/EC on undesirable substances in animal feed. It should be noted that heavy metal content of the biomass in the current study was measured in algae paste $(\sim 80 \%$ moisture content) rather than in dry biomass. Ideally, future studies should also assess the abundance of heavy metals in dry microalgae biomass, as animal feed supplements are likely to be manufactured from dry biomass rather than from algae paste. Besides a high binding affinity for heavy metals, microalgae can also have reactive groups to bind other types of pollutants which might interfere with downstream processing (Leong and Chang, 2020). Therefore, the abundance of other undesirable substances such as organic contaminants (e.g., dioxin, mycotoxins) and pesticides should also be assessed.

Next to biomass safety, also biomass content determines the applicability of wastewater-derived microalgal biomass in feed production. While commercially available Chlorella species (not cultivated on wastewater) typically consist of $52 \%$ protein, $7.5 \%$ lipid, and $24.3 \%$ carbohydrate per 
dry matter (Stiles et al., 2018), the produced biomass in the current study had a lower protein content $(\sim 20 \%)$ and a higher lipid $(\sim 17 \%)$ and carbohydrate $(\sim 35 \%)$ content. Because alternative feed sources, such as microalgal biomass, should have a high protein level (Becker, 2013; Stiles et al., 2018), future research should assess to what extent the nutritional composition of wastewater-derived microalgal biomass can be manipulated (e.g., harvesting at a different moment of the growth cycle, nutrient supplementation, light exposure, different microalgae species). Moreover, how this affects other nutritional characteristics, including a balanced amino acid profile, high digestibility and palatability, should be documented in order to further explore the potential of wastewater-derived microalgal biomass for feed production. Lastly, it is worth noting that besides its potential use as feedstock for biofuel and food/feed, microalgae biomass produced on wastewater may also have applications in other sectors (e.g., agriculture, cosmetics, dyes, biopolymers) to further fuel the viability of this technology (Slompo et al., 2020; Lutzu et al., 2021). Overall, the results of the current study add to our growing knowledge on the valorization opportunities of microalgal biomass cultivated on wastewater, and pave the way for a more sustainable use and reuse of resources.

\section{DATA AVAILABILITY STATEMENT}

The raw data supporting the conclusions of this article will be made available by the authors, without undue reservation.

\section{REFERENCES}

Acién Fernández, F. G., Fernández Sevilla, J. M., and Molina Grima, E. (2019). Costs Analysis of Microalgae Production. Biofuels from Algae. 551-566. doi:10.1016/b978-0-444-64192-2.00021-4

Alcántara, C., Posadas, E., Guieysse, B., and Muñoz, R. (2015). "Microalgae-based Wastewater Treatment," in Handbook of Marine Microalgae: Biotechnology Advances. Editor S. Kim (Elsevier), 439-455. doi:10.1016/B978-0-12-8007761.00029-7

Ansari, F. A., Singh, P., Guldhe, A., and Bux, F. (2017). Microalgal Cultivation Using Aquaculture Wastewater: Integrated Biomass Generation and Nutrient Remediation. Algal Res. 21, 169-177. doi:10.1016/j.algal.2016.11.015

Asadi, P., Rad, H. A., and Qaderi, F. (2019). Comparison of Chlorella Vulgaris and Chlorella Sorokiniana pa.91 in post Treatment of Dairy Wastewater Treatment Plant Effluents. Environ. Sci. Pollut. Res. 26, 29473-29489. doi:10.1007/s11356019-06051-8

Bates, D., Maechler, M., Bolker, B., Walker, S., Christensen, R. H. B., Singmann, H., et al. (2017). lme4: Linear Mixed-Effects Models Using Eigen and S4. R Package Version 1.1-14. Available at: http://cran.r-project.org/package=lme4 (Accessed November 16, 2020).

Becker, E. W. (2013). "Microalgae for Human and Animal Nutrition," in Handbook of Microalgal Culture: Applied Phycology and Biotechnology. Editors A. Richmond and Q. Hu. Second Edi (John Wiley \& Sons), 461-503. doi:10.1002/9781118567166.ch25

Bhatia, S. K., Mehariya, S., Bhatia, R. K., Kumar, M., Pugazhendhi, A., Awasthi, M. K., et al. (2021). Wastewater Based Microalgal Biorefinery for Bioenergy Production: Progress and Challenges. Sci. Total Environ. 751, 141599. doi:10.1016/j.scitotenv.2020.141599

\section{AUTHOR CONTRIBUTIONS}

ET: Conceptualization, methodology, formal analysis, writing-original draft; FS: Conceptualization, methodology, writing-review and editing; AC: Methodology, writing-review and editing; RV: Conceptualization, methodology, writing-review and editing; IN: Methodology, writing-review and editing; PB: Conceptualization, funding acquisition, writing-review and editing; SM: Conceptualization, funding acquisition, writing-review and editing.

\section{FUNDING}

This work was funded by OVAM-Vlaanderen Circulair-project nr. 2019-OC-SO-250.

\section{ACKNOWLEDGMENTS}

We thank E. Gebruers and S. Goossens for their help with conceiving the project and chemical analyses, respectively.

\section{SUPPLEMENTARY MATERIAL}

The Supplementary Material for this article can be found online at: https://www.frontiersin.org/articles/10.3389/fenvs.2021.679917/ full\#supplementary-material

Bos, H. L., and Broeze, J. (2020). Circular Bio-based Production Systems in the Context of Current Biomass and Fossil Demand. Biofuels, Bioprod. Bioref. 14, 187-197. doi:10.1002/bbb.2080

Caporgno, M. P., Taleb, A., Olkiewicz, M., Font, J., Pruvost, J., Legrand, J., et al. (2015). Microalgae Cultivation in Urban Wastewater: Nutrient Removal and Biomass Production for Biodiesel and Methane. Algal Res. 10, 232-239. doi:10.1016/j.algal.2015.05.011

Chen, C.-Y., Kuo, E.-W., Nagarajan, D., Ho, S.-H., Dong, C.-D., Lee, D.-J., et al. (2020). Cultivating Chlorella Sorokiniana AK-1 with Swine Wastewater for Simultaneous Wastewater Treatment and Algal Biomass Production. Bioresour. Technology 302, 122814. doi:10.1016/j.biortech.2020.122814

Chew, K. W., Yap, J. Y., Show, P. L., Suan, N. H., Juan, J. C., Ling, T. C., et al. (2017). Microalgae Biorefinery: High Value Products Perspectives. Bioresour. Technology. 229, 53-62. doi:10.1016/j.biortech.2017.01.006

Chi, Z., O'Fallon, J. V., and Chen, S. (2011). Bicarbonate Produced from Carbon Capture for Algae Culture. Trends Biotechnol. 29, 11. doi:10.1016/ j.tibtech.2011.06.006

Cho, S., Luong, T. T., Lee, D., Oh, Y.-K., and Lee, T. (2011). Reuse of Effluent Water from a Municipal Wastewater Treatment Plant in Microalgae Cultivation for Biofuel Production. Bioresour. Technology 102, 8639-8645. doi:10.1016/ j.biortech.2011.03.037

Clark, J. H. (2019). Green Biorefinery Technologies Based on Waste Biomass. Green. Chem. 21 (6), 1168-1170. doi:10.1039/c9gc90021g

Cole, J. J., and Prairie, Y. T. (2009). “Dissolved CO2,"In. Encyclopedia of Inland Waters. Editor G E. Likens (Oxford: Elsevier), Vol. 2, 30-34. doi:10.1016/b978012370626-3.00091-0

Cordell, D., and White, S. (2014). Life's Bottleneck: Sustaining the World's Phosphorus for a Food Secure Future. Annu. Rev. Environ. Resour. 39, 161-188. doi:10.1146/annurev-environ-010213-113300 
Deng, X., Li, D., Xue, C., Chen, B., Dong, J., Tetteh, P. A., et al. (2019). Cultivation of Chlorella Sorokiniana Using Wastewaters from Different Processing Units of the Silk Industry for Enhancing Biomass Production and Nutrient Removal. J. Chem. Technol. Biotechnol. 95, 264-273. doi:10.1002/jctb.6230

El-Chichakli, B., Von Braun, J., Lang, C., Barben, D., and Philp, J. (2016). Policy: Five Cornerstones of a Global Bioeconomy. Nature. 535, 221-223. doi:10.1038/ 535221a

Eladel, H., Abomohra, A. E.-F., Battah, M., Mohmmed, S., Radwan, A., and Abdelrahim, H. (2019). Evaluation of Chlorella Sorokiniana Isolated from Local Municipal Wastewater for Dual Application in Nutrient Removal and Biodiesel Production. Bioproc. Biosyst. Eng. 42, 425-433. doi:10.1007/s00449018-2046-5

Gan, K., Mou, X., Xu, Y., and Wang, H. (2014). Application of Ozonated Piggery Wastewater for Cultivation of Oil-Rich Chlorella Pyrenoidosa. Bioresour. Technology 171, 285-290. doi:10.1016/j.biortech.2014.08.105

Geng, Y., Sarkis, J., and Bleischwitz, R. (2019). How to Globalize the Circular Economy. Nature 565, 153-155. doi:10.1126/science.122705910.1038/d41586019-00017-z

Goldman, J. C., and Brewer, P. G. (1980). Effect of Nitrogen Source and Growth Rate on Phytoplankton-Mediated Changes in Alkalinity. Limnol. Oceanogr. 25, 352-357.

Grover, J. P. (2000). Resource Competition and Community Structure in Aquatic Micro-organisms: Experimental Studies of Algae and Bacteria along a Gradient of Organic Carbon to Inorganic Phosphorus Supply. J. Plankton Res. 22, 1591-1610. doi:10.1093/plankt/22.8.1591

Guldhe, A., Kumari, S., Ramanna, L., Ramsundar, P., Singh, P., Rawat, I., et al. (2017). Prospects, Recent Advancements and Challenges of Different Wastewater Streams for Microalgal Cultivation. J. Environ. Manage. 203, 299-315. doi:10.1016/j.jenvman.2017.08.012

Haas, W., Krausmann, F., Wiedenhofer, D., and Heinz, M. (2015). How Circular Is the Global Economy?: An Assessment of Material Flows, Waste Production, and Recycling in the European union and the World in 2005. J. Ind. Ecol. 19 (5), 765-777. doi:10.1111/jiec.12244

Hamed, I. (2016). The Evolution and Versatility of Microalgal Biotechnology: A Review. Compr. Rev. Food Sci. Food Saf. 15, 1104-1123. doi:10.1111/15414337.12227

Higgins, B. T., and VanderGheynst, J. S. (2014). Effects of Escherichia coli on Mixotrophic Growth of Chlorella Minutissima and Production of Biofuel Precursors. PLoS ONE. 9, e96807. doi:10.1371/journal.pone.0096807

Hulatt, C. J., and Thomas, D. N. (2011). Productivity, Carbon Dioxide Uptake and Net Energy Return of Microalgal Bubble Column Photobioreactors. Bioresour. Technology 102, 5775-5787. doi:10.1016/j.biortech.2011.02.025

Ievina, B., and Romagnoli, F. (2020). Potential of Chlorella Species as Feedstock for Bioenergy Production: A Review. Environ. Clim. Tech. 24, 203-220. doi:10.2478/rtuect-2020-0067

Kümmerer, K., Clark, J. H., and Zuin, V. G. (2020). Rethinking Chemistry for a Circular Economy. Science 367 (6476), 369-370. doi:10.1126/ science.aba4979

Larsen, T. A., Hoffmann, S., Lüthi, C., Truffer, B., and Maurer, M. (2016). Emerging Solutions to the Water Challenges of an Urbanizing World. Science 352 (6288), 928-933. doi:10.1126/science.aad8641

Le Chevanton, M., Garnier, M., Bougaran, G., Schreiber, N., Lukomska, E., Bérard, J.-B., et al. (2013). Screening and Selection of Growth-Promoting Bacteria for Dunaliella Cultures. Algal Res. 2, 212-222. doi:10.1016/j.algal.2013.05.003

Lenth, R., and Love, J. (2017). Lsmeans: Least-Squares Means Version 2, 27-61. Available at: http://cran.r-project.org/package=lsmeans (Accessed November 16, 2020).

Leong, Y. K., and Chang, J.-S. (2020). Bioremediation of Heavy Metals Using Microalgae: Recent Advances and Mechanisms. Bioresour. Technology 303, 122886. doi:10.1016/j.biortech.2020.122886

Lian, J., Wijffels, R. H., Smidt, H., and Sipkema, D. (2018). The Effect of the Algal Microbiome on Industrial Production of Microalgae. Microb. Biotechnol. 11, 806-818. doi:10.1111/1751-7915.13296

Lutzu, G. A., Ciurli, A., Chiellini, C., Di Caprio, F., Concas, A., and Dunford, N. T. (2021). Latest Developments in Wastewater Treatment and Biopolymer Production by Microalgae. J. Environ. Chem. Eng. 9, 104926. doi:10.1016/ j.jece.2020.104926
Markou, G. (2015). Fed-batch Cultivation of Arthrospira and Chlorella in Ammonia-Rich Wastewater: Optimization of Nutrient Removal and Biomass Production. Bioresour. Technology 193, 35-41. doi:10.1016/ j.biortech.2015.06.071

Markou, G., Iconomou, D., and Muylaert, K. (2016). Applying Raw Poultry Litter Leachate for the Cultivation of Arthrospira Platensis and Chlorella Vulgaris. Algal Res. 13, 79-84. doi:10.1016/j.algal.2015.11.018

Metting, F. B. (1996). Biodiversity and Application of Microalgae. J. Ind. Microbiol. Biotechnol. 17, 477-489. doi:10.1007/BF01574779

Mobin, S., and Alam, F. (2017). Some Promising Microalgal Species for Commercial Applications: A Review. Energ. Proced. 110, 510-517. doi:10.1016/j.egypro.2017.03.177

Mohsenpour, S. F., Hennige, S., Willoughby, N., Adeloye, A., and Gutierrez, T. (2021). Integrating Micro-algae into Wastewater Treatment: A Review. Sci. Total Environ. 752, 142168. doi:10.1016/j.scitotenv.2020.142168

Nagarajan, D., Lee, D.-J., Chen, C.-Y., and Chang, J.-S. (2020). Resource Recovery from Wastewaters Using Microalgae-Based Approaches: A Circular Bioeconomy Perspective. Bioresour. Technology 302, 122817. doi:10.1016/ j.biortech.2020.122817

Nahm, K. H. (2003). Evaluation of the Nitrogen Content in Poultry Manure. World's Poult. Sci. J. 59, 77-88. doi:10.1079/WPS20030004

Norsker, N.-H., Barbosa, M. J., Vermuë, M. H., and Wijffels, R. H. (2011). Microalgal Production - A Close Look at the Economics. Biotechnol. Adv. 29, 24-27. doi:10.1016/j.biotechadv.2010.08.005

Park, S., Kim, J., Yoon, Y., Park, Y., and Lee, T. (2015). Blending Water- and Nutrient-Source Wastewaters for Cost-Effective Cultivation of High Lipid Content Microalgal Species Micractinium Inermum NLP-F014. Bioresour. Technology 198, 388-394. doi:10.1016/j.biortech.2015.09.038

Patrinou, V., Tsolcha, O. N., Tatoulis, T. I., Stefanidou, N., Dourou, M., MoustakaGouni, M., et al. (2020). Biotreatment of Poultry Waste Coupled with Biodiesel Production Using Suspended and Attached Growth Microalgal-Based Systems. Sustainability 12, 5024. doi:10.3390/su12125024

Peccia, J., Haznedaroglu, B., Gutierrez, J., and Zimmerman, J. B. (2013). Nitrogen Supply Is an Important Driver of Sustainable Microalgae Biofuel Production. Trends Biotechnol. 31 (3), 134-138. doi:10.1016/j.tibtech.2013.01.010

Pradhan, D., Sukla, L. B., Mishra, B. B., and Devi, N. (2019). Biosorption for Removal of Hexavalent Chromium Using Microalgae Scenedesmus Sp. J. Clean. Prod. 209, 617-629. doi:10.1016/j.jclepro.2018.10.288

Qin, L., Shu, Q., Wang, Z., Shang, C., Zhu, S., Xu, J., et al. (2014). Cultivation of Chlorella Vulgaris in Dairy Wastewater Pretreated by UV Irradiation and Sodium Hypochlorite. Appl. Biochem. Biotechnol. 172, 1121-1130. doi:10.1007/ s12010-013-0576-5

Ramanan, R., Kim, B.-H., Cho, D.-H., Oh, H.-M., and Kim, H.-S. (2016). Algaebacteria Interactions: Evolution, Ecology and Emerging Applications. Biotechnol. Adv. 34, 14-29. doi:10.1016/j.biotechadv.2015.12.003

Ramsundar, P., Guldhe, A., Singh, P., and Bux, F. (2017). Assessment of Municipal Wastewaters at Various Stages of Treatment Process as Potential Growth media for Chlorella Sorokiniana under Different Modes of Cultivation. Bioresour. Technology 227, 82-92. doi:10.1016/j.biortech.2016.12.037

Rice, E. W., Baird, R. B., and Eaton, A. D. (2017). Standard Methods for the Examination of Water and Wastewater. 23rd ed.. American Public Health Association/American Water Works Association/Water Environment Federation.

Rösch, C., Roßmann, M., and Weickert, S. (2019). Microalgae for Integrated Food and Fuel Production. GCB Bioenergy. 11, 326-334. doi:10.1111/gcbb.12579

Salama, E.-S., Kurade, M. B., Abou-Shanab, R. A. I., El-Dalatony, M. M., Yang, I.-S., Min, B., et al. (2017). Recent Progress in Microalgal Biomass Production Coupled with Wastewater Treatment for Biofuel Generation. Renew. Sustainable Energ. Rev. 79, 1189-1211. doi:10.1016/j.rser.2017.05.091

Schandl, H., Hatfield-Dodds, S., Wiedmann, T., Geschke, A., Cai, Y., West, J., et al. (2016). Decoupling Global Environmental Pressure and Economic Growth: Scenarios for Energy Use, Materials Use and Carbon Emissions. J. Clean. Prod. 132, 45-56. doi:10.1016/j.jclepro.2015.06.100

Sinha, E., Michalak, A. M., and Balaji, V. (2017). Eutrophication Will Increase during the 21st century as a Result of Precipitation Changes. Science 357, 405-408. doi:10.1126/science.aan2409

Slompo, N. D. M., Quartaroli, L., Fernandes, T. V., Silva, G. H. R. d., and Daniel, L. A. (2020). Nutrient and Pathogen Removal from Anaerobically Treated Black 
Water by Microalgae. J. Environ. Manage. 268, 110693. doi:10.1016/ j.jenvman.2020.110693

Sriram, S., and Seenivasan, R. (2012). Coupling of Algal Biofuel Production with Wastewater. J. Algal Biomass Utilization. 3, 9-13.

Stiles, W. A. V., Styles, D., Chapman, S. P., Esteves, S., Bywater, A., Melville, L., et al. (2018). Using Microalgae in the Circular Economy to Valorise Anaerobic Digestate: Challenges and Opportunities. Bioresour. Technology 267, 732-742. doi:10.1016/j.biortech.2018.07.100

Vigani, M. (2020). "The Bioeconomy of Microalgae-Based Processes and Products," in Handbook of Microalgae-Based Processes and Products. Editors E. Jacob-Lopes, M. Manzoni Maroneze, M. I. Queiroz, and L. Queiroz Zepka (Elsevier), 799-821. doi:10.1016/b978-0-12-818536-0.00029-4

Wang, J., Zhou, W., Chen, H., Zhan, J., He, C., and Wang, Q. (2019). Ammonium Nitrogen Tolerant Chlorella Strain Screening and its Damaging Effects on Photosynthesis. Front. Microbiol. 9, 3250. doi:10.3389/fmicb.2018.03250

Wang, S.-K., Wang, X., Miao, J., and Tian, Y.-T. (2018). Tofu Whey Wastewater Is a Promising Basal Medium for Microalgae Culture. Bioresour. Technology 253, 79-84. doi:10.1016/j.biortech.2018.01.012

Waters, C. N., Zalasiewicz, J., Summerhayes, C., Barnosky, A. D., Poirier, C., Ga uszka, A., et al. (2016). The Anthropocene Is Functionally and Stratigraphically Distinct from the Holocene. Science 351 (6269), aad2622. doi:10.1126/science.aad2622
Wicker, R. J., Kumar, G., Khan, E., and Bhatnagar, A. (2021). Emergent green Technologies for Cost-Effective Valorization of Microalgal Biomass to Renewable Fuel Products under a Biorefinery Scheme. Chem. Eng. J. 415. doi:10.1016/j.cej.2021.128932

Wild, K. J., Steingaß, H., and Rodehutscord, M. (2019). Variability of in vitro ruminal fermentation and nutritional value of cell-disrupted and nondisrupted microalgae for ruminants. GCB Bioenergy 11, 345-359. doi:10.1111/gcbb.12539

Zawartka, P., Burchart-Korol, D., and Blaut, A. (2020). Model of Carbon Footprint Assessment for the Life Cycle of the System of Wastewater Collection, Transport and Treatment. Sci Rep. 10, 5799. doi:10.1038/s41598-020-62798-y

Conflict of Interest: The authors declare that the research was conducted in the absence of any commercial or financial relationships that could be construed as a potential conflict of interest.

Copyright (C) 2021 Thoré, Schoeters, De Cuyper, Vleugels, Noyens, Bleyen and Van Miert. This is an open-access article distributed under the terms of the Creative Commons Attribution License (CC BY). The use, distribution or reproduction in other forums is permitted, provided the original author(s) and the copyright owner(s) are credited and that the original publication in this journal is cited, in accordance with accepted academic practice. No use, distribution or reproduction is permitted which does not comply with these terms. 